\title{
Konsep ergonomi kultural nusantara dalam pendidikan dasar Desain Produk ITENAS
}

\author{
Edi Setiadi Putra*, Mohamad Arif Waskito \\ Program Studi Desain Produk, Fakultas Seni Rupa dan Desain, Institut Teknologi Nasional Bandung, Indonesia
}

\begin{abstract}
This study aims to reveal the existence of the concept of Cultural Ergonomics or Ergoculture, as a relevant term to describe the cultural influence of a nation in the principles of modern ergonomics. Ergonomics or Human Factor, is one of the important sciences to be studied by Product Design students, because it is a determining factor in achieving the predicate of the feasibility of using a product. Comfortability factors, efficiency and productivity are the benchmarks for the success of product design process. The study in this paper is a review of the process of design basic education that needs to introduce the ergonomic aspects of Indonesian people to a particular field of work based on cultural values. Not all principles of universal ergonomics are relevant to the cultural patterns of Indonesian society. Ergonomics studies in essential design basic education are delivered early to strengthen the understanding of cultural values from the ergonomic point of view of Indonesian society in general. This study is the beginning of the thought of the need to strengthen cultural aspects in Ergonomics applied to the study of Industrial Product Design in Indonesia.
\end{abstract}

Key words: ergonomics, ergo-culture, culture, product design

\begin{abstract}
Abstrak
Penelitian ini bertujuan untuk mengungkap adanya konsep Ergonomi Kultural atau Ergokultur, sebagai istilah yang relevan untuk menggambarkan adanya pengaruh budaya suatu bangsa dalam prinsip ergonomi modern. Ilmu Ergonomi atau Faktor Manusia, merupakan salah satu ilmu pengetahuan yang penting untuk dipelajari mahasiswa Program Studi Desain Produk, karena merupakan faktor penentu dalam meraih predikat kelayakan pakai suatu produk. Faktor kenyamanan kerja, efisiensi kerja dan produktivitas kerja menjadi tolok ukur keberhasilan perancangan produk. Kajian dalam makalah ini merupakan tinjauan mengenai proses pendidikan dasar desain yang perlu memperkenalkan aspek ergonomi manusia Indonesia terhadap suatu bidang kerja tertentu yang berlandaskan nilai budaya. Tidak semua prinsip ergonomi universal itu relevan dengan pola budaya masyarakat Indonesia. Kajian ergonomi dalam pendidikan dasar desain penting disampaikan sejak dini untuk menguatkan pemahaman nilai-nilai budaya dari sudut pandang ergonomis masyarakat Indonesia pada umumnya. Kajian ini merupakan awal dari pemikiran perlunya penguatan aspek budaya dalam ilmu Ergonomi yang diterapkan pada studi Desain Produk Industri di Indonesia.
\end{abstract}

Kata kunci: ergonomi, ergokultural, budaya, desain produk

\section{Pendahuluan}

Dalam studi Desain Produk di Itenas, mahasiswa tingkat pendidikan dasar desain atau yang baru belajar desain, diberikan pelatihan keterampilan dasar menggambar dan berkreasi dengan berbagai material, dalam rangka memahami nilai-nilai estetika. Kesadaran estetis tidak hanya diperoleh berdasarkan uraian teoritis dan kajian filosofis, tetapi perlu dilatih secara terkoordinasi antara hati, pikiran dan sistem syaraf motorik yang mengerjakan suatu kreasi secara terprogram berdasarkan kompetensi indrawi.

Mahasiswa baru dilatih untuk memahami estetika, yang menjadi dasar nilai suatu struktur bentuk memperoleh keindahan, keserasian dan kesempurnaan, baik melalui proses menggambar maupun mengolah rupa bentukan dwimatra dan trimatra. Menggambar merupakan salah satu bentuk

\footnotetext{
* Corresponding author; e-mail : edsetia@itenas.ac.id
} 
komunikasi yang sangat efektif. Melalui gambar, mahasiswa dapat memperkenalkan gagasan, memilih alternatif dan mendapatkan jawaban dari suatu permasalahan secara visual. Berbagai teknik menggambar, perlu dilatih dan diperkenalkan sejak dini agar mahasiswa memiliki banyak kemungkinan untuk berkarya dan memperoleh nilai kreativitas yang tinggi. (Wallschlaeger \& Busic-Snyder, 1992).

Sejak awal perlu disadari oleh semua pihak, bahwa pengalaman menerima permasalahan estetika, pada dasarnya sangat dipengaruhi oleh beragam pertimbangan nilai yang mendasari akar budaya setiap orang. Mengapa calon desainer produk perlu diajari seni? Estetika? Aspek keindahan rupa? Penilaian estetis? Pertanyaan-pertanyaan inilah yang seringkali mengguncang para pendidik dan perupa. Pertanyaanpertanyaan ini sesungguhnya telah berusaha dijawab oleh para pemikir sejak masa klasik, renaisans, modern dan posmodern Sutrisno, 2017).

Kepedulian para pemikir untuk mencoba menjawab gugus pertanyaan tersebut, ternyata tidak serta merta dibatasi, dibahas dan diulas pada kajian ilmu tertentu (misalnya pada sejarah seni, atau ilmu budaya) namun telah melintasi ranah dan melompati batas yang ada diantara disiplin-disiplin ilmu, seperti sosiologi, politik, lingusitik, antropologi dan filsafat estetika.

Dalam proses kajian desain produk, nilai benar lebih utama dari pada nilai indah. Sebab nilai keindahan akan terungkap tatkala suatu produk telah dirancang dengan cara yang benar, terukur dan sistematis. Kerunutan proses pemecahan permasalahan dan penerapan solusi yang sistematis dalam proses perancangan produk, merupakan keharusan yang sangat penting, karena dapat mengantarkan pola pemikiran perancang memenuhi standar pikir yang benar dan utuh. Keutuhan pemikiran seorang perancang terungkap dalam sistem pola pikir yang menempatkan kebenaran logis sebagai inti narasi suatu keputusan desain.

Pola pemikiran yang logis, alur yang runut, terukur serta sistematis, merupakan tuntutan dasar dalam memenuhi kelayakan konsep desain produk. Konsepsi yang logis dari suatu desain produk merupakan dasar kelayakan pakai, kelayakan produksi, dan kelayakan promosi yang memberi nilai tambah penting bagi kualitas hidup manusia. Dengan demikian, dasar dari suatu sistem filsafat desain produk adalah menempatkan kedudukan idea kreatif yang logis sebagai pembentuk nilai estetis, yang terwujud dari simpulan estetika bentuk rupa, sistem kerja dan estetika material.

Ketika mahasiswa diperkenalkan dengan hakikat dan kebenaran murni dari suatu material, adalah sama dengan memperkenalkan estetika keindahan material, sehingga mahasiswa dapat mengeksplorasi idea untuk mengkreasi pemanfaatan material dengan konsep estetika yang dipahaminya secara individual. Hal inilah yang memacu kemunculan keunikan dan kebaruan yang tidak dipengaruhi secara langsung oleh sistem kebenaran kolektif yang divisualisasikan oleh dosen pengajar estetika bentuk.

Mahasiswa yang mengikuti tutorial estetika melalui olah material dalam mata kuliah rupa dasar trimatra atau nirmana tridimensional, dapat memahami nilai estetika secara tepat dengan fasilitas pemikiran yang logis. Idea kreatifnya dalam mengolah material sedemikian rupa sehingga muncul visualisasi bentuk yang unik dan baru, pada dasarnya didasari oleh sistem pemikiran logika yang kuat dan mengakar. Mahasiswa yang menemukan sesuatu yang baru dan unik, namun tidak dapat menjelaskan penemuannya dalam narasi verbal maupun tulisan yang runut, adalah pada dasarnya sedang memperlihatkan suatu kekacauan psikis. Suatu objek estetis yang hadir secara kebetulan atau ketidaksengajaan merupakan suatu bentuk gangguan pemikiran yang nyata.

Pemahaman objek estetis yang bersumber dari keindahan material, dipengaruhi oleh penggunaan alat kerja dan sistem kerjanya yang dipahami secara umum. Pada proses pembentukan kreasi baru dari suatu subjek material, terdapat nilai-nilai logis yang mempengaruhi manusia untuk bekerja sesuai prosedur. Penggunaan alat kerja yang benar dapat mencegah bahaya kecelakaan dan mengurangi gangguan psikis. Gangguan psikis dalam praktek olah rupa adalah kemunculan keisengan yang menyimpang dan menimbulkan kejenuhan berpikir dan bertindak, sehingga berujung pada kemalasan dan ketidakpahaman yang berulang, hal ini yang sering dialami mahasiswa apabila bekerja non-prosedural.

Kemunculan kreasi iseng yang terbentuk dari pemikiran yang logis, adalah merupakan awal dari kreativitas yang berkualitas tinggi. Konsep kreasi terbaru yang masuk akal dengan proses yang memenuhi standar prosedur, akan menjadi suatu karya terbaik yang mudah dijelaskan dan dipahami oleh masyarakat. Penelitian ini menjadi penting dilakukan dalam rangka penerapan kurikulum berdasarkan Standar Nasional Indonesia, dalam beberapa mata kuliah yang diselenggarakan untuk mahasiswa yang memasuki program pendidikan dasar desain atau studio rupa dasar di Program Studi Desain Produk.

\section{Bahan dan metode}

Program Studi Desain Produk, Institut Teknologi Nasional (ITENAS) yang berkedudukan di Bandung 
Edi Setiadi Putra \& Mohamad Arif Waskito

Konsep ergonomi kultural nusantara dalam pendidikan dasar Desain Produk ITENAS

merupakan salah satu institusi pendidikan desain yang masih menerapkan pola kerja Bauhaus, dimana terdapat empat mata kuliah rupa dasar yang memiliki kandungan estetika yang sangat tinggi yaitu menggambar bentuk, menggambar konstruksi, rupa dasar dwimatra dan rupa dasar trimatra. Dengan melatih keterampilan menggambar dan mengolah rupa, diharapkan mahasiswa memahami estetika dari minimal empat sudut pandang yang berbeda.

Keempat mata kuliah ini hanya mengasah ketajaman berpikir dan bertindak terampil dalam memutuskan suatu pemikiran kreatif berdasarkan prosedur belajar yang sistematis dan terukur. Kedalaman pemikiran estetika dan pencapaian kualitas karya, dilengkapi oleh beberapa mata kuliah pendukung antara lain: Berfikir (dan bertindak) Kreatif, Wawasan (budaya) Nusantara dan ideologi nasionalisme (antara lain: mata kuliah Pancasila dan Kewarganegaraan).

Pada mata kuliah Berfikir Kreatif, mahasiswa dibekali tanggung jawab untuk mampu mengolah pikir yang logis holistik, yaitu kemampuan memahami suatu gagasan yang menarik dan mewujudkannya dalam visualisasi yang cermat dengan narasi argumentasi yang runut dan jelas. Mempertanyakan gagasan merupakan salah satu sistem apresiasi dan pengujian mandiri terhadap kemunculan idea kreatif yang berkarakter. Setiap mahasiswa memiliki karakter bawaan yang setiap saat muncul mengiringi semua gagasan atau idea kreatifnya. Dengan demikian, nilai benar menjadi sangat beragam dan bersifat relatif. Pada masa kini, salah satu upaya keras yang dilakukan para pengajar Berfikir Kreatif adalah bagaimana menjadikan mahasiswa menjadi insan yang lancar bertanya dan menjawab. Mahasiswa yang segan bertanya, dianggap sebagai salah satu gejala kemunduran psikis.

Mata kuliah Wawasan Nusantara atau wawasan budaya Nusantara, merupakan mata kuliah yang mengasuh mahasiswa untuk memahami dan menikmati cara berkarya para leluhur bangsa, yang tersebar dalam berbagai suku bangsa dan aneka budaya. Kajian tentang ragam hias dan seni tradisional yang mengakar dalam kehidupan berbagai suku bangsa di Indonesia, merupakan materi kajian yang sangat berlimpah dan mewah. Mahasiswa dapat melihat kondisi geografis budaya bangsa yang heterogen dalam akar yang homogen. Pemahaman terhadap diri sendiri merupakan upaya untuk memberikan kesadaran logis bahwa apa yang dimiliki merupakan anugerah yang harus disyukuri dan dihormati, melalui proses budidaya karya yang semakin berkualitas tinggi. Kesadaran terhadap budaya bangsa diperlukan dalam rangka mengembangkan kreativitas berkarya yang dijiwai oleh karakter bangsa sendiri.

Mata kuliah yang memuat kandungan ideologis dan nasionalisme, yang sangat diperlukan oleh semua generasi muda dalam memahami jati dirinya, dipenuhi oleh mata kuliah Pancasila dan Kewarganegaraan, yang di Itenas dikemas dalam suatu program Bela Negara, kegiatan ini cukup dinikmati mahasiswa karena mampu menguras adrenalin dengan keceriaan yang optimal. Pancasila dan Kewarganegaraan yang awalnya dianggap sebagai mata kuliah yang menjemukan karena telah dipelajari bertahun-tahun dalam program pendidikan sekolah dasar dan menengah, telah beralih rupa menjadi agenda yang memiliki kesan yang mendalam. Walau mendapat sedikit sentuhan militeristik yang tegas dan disiplin yang keras, ternyata dapat menumbuhkan sosok insan yang tenang, damai, toleran, berhati nurani, religius, tekun, dan giat belajar.

Keseluruhan program pendidikan untuk mahasiswa studio dasar desain ini tampak lengkap dan berdampak sangat positif terhadap pembentukan karakter yang hebat, unggul dan berkualitas tinggi. Karakter mahasiswa ini merupakan dasar yang penting dalam studi Desain Produk yang tidak hanya memberikan ilmu pengetahuan yang mumpuni, keterampilan yang tinggi dan kemampuan berfikir yang logis kreatif, juga sebagai benteng ideologi bangsa, yang mampu menumbuhkan pilar pertahanan mental ideologis yang kokoh melalui penguatan kebanggaan terhadap karya cipta bangsa sendiri. Program ini terkait dengan penguatan aspek budaya bangsa yang berkarakter terbaik. Karya kreasi yang dilandasi nilai budaya, merupakan suatu karya budaya yang bernilai tinggi dan layak untuk mendapatkan apresiasi yang terbaik.

Penelitian ini secara khusus mengkaji adanya penerapan prinsip ergonomi kultural dalam proses studi estetika dalam Studio Dasar Desain di Itenas. Prinsip ergonomi yang dipindai adalah terkait dengan pemahaman mahasiswa dalam memahami estetika melalui keterampilan menggambar figur manusia seutuhnya dengan cara yang benar.

\section{Hasil dan pembahasan}

Program Studi Desain Produk Itenas mempersiapkan mahasiswa untuk mampu berkreasi mandiri, melalui tahapan Pendidikan Dasar Desain atau Studio Dasar Desain (Basic Design Studio) yang harus ditempuh mahasiswa selama dua semester. 
Matakuliah utama studio dasar desain meliputi: Menggambar Bentuk, Menggambar Konstruktif, Rupa Dasar 2D, dan Rupa Dasar 3D. Empat matakuliah ini merupakan matakuliah studio berbobot masingmasing 3 SKS untuk durasi aktif 6 jam. Empat matakuliah ini diyakini sebagai empat unsur utama yang sangat penting dalam mempelajari estetika, sebagai dasar kompetensi kreatif seorang perancang produk.

Dalam studio dasar desain, dipelajari dengan cara "learning by doing" untuk memahami nilai-nilai estetika yang terkandung dalam suatu visualisasi objek melalui olahan bentuk, konstruksi garis, bidang, warna, tekstur dan ruang. Semua mahasiswa perlu mendapatkan wawasan yang cukup luas dan mendalam tentang beberapa aspek estetis dalam studi desain produk, yaitu: (1) memahami fungsi, makna dan karakter material, baik material alam maupun artifisial. Dalam latihan eksplorasi material, mahasiswa memiliki pengetahuan awal berupa ruang lingkup material, sifat dan karakternya, sehingga dapat menerima konsep "kejujuran material” sebagai keniscayaan dan bersifat logis realistis. (2) memahami proses mengolah rasa, karsa dan karya sebagai langkah konkrit yang mewujudkan nilai-nilai estetika, dari yang samar menjadi nyata, dari tersembunyi menjadi terbuka, serta dari yang tersirat menjadi tersurat dalam bentuk agumentasi naratif yang runut dan logis pula. Pada proses ini, mahasiswa memperdalam keterampilan khusus dalam membentuk, mengolah, mengkomparasi, mengkolaborasi dan menganalisis serta mensintesis alternatif gagasan. (3) meningkatkan kemampuan membuat interpretasi, mengapresiasi dan mempresentasikan suatu karya kreatifnya, melalui deskripsi singkat yang runut, jelas dan mudah dipahami masyarakat umum. Kemampuan menguraikan gagasan, baik secara lisan dan tulisan merupakan kebutuhan mutlak untuk diterimanya suatu idea kreatif dari seorang kreator.

Selain konsep 'kejujuran material' (material honesty) dan 'kejujuran proses berkarya' (creative honesty) yang bersifat fisikis, mahasiswa juga memerlukan 'kejujuran rasa' (honesty of taste) yang bersifat batiniah atau psikologis, yaitu kemampuan memaparkan makna filosofis sederhana dari kreasi yang dirancangnya. Bentuk pemahaman makna filosofis sederhana yang perlu diketahui mahasiswa tingkat awal adalah berupa kemampuan menjelaskan proses pencapaian hasil karyanya, sehingga keputusan kreasinya merupakan hasil pemikiran kreatif yang argumentatif. Mahasiswa yang dapat menjelaskan kronologis kreasinya, pada umumnya dapat memahami makna benar dan salah dalam suatu keputusan kreasi.

Nilai benar dan salah merupakan nilai kualitatif yang jelas batasannya, sedangkan nilai baik dan buruk merupakan nilai kualitiatif yang bersifat relatif. Nilai benar dan salah dari suatu karya kreasi ditandai dengan adanya keterpahaman sesuatu yang bersifat logis dan masuk akal. Pembelajaran di perguruan tinggi bertujuan untuk membangun pola berpikir dan berfikir kreatif dalam struktur kognitif dan membangkitkan kemampuan berpikir mahasiswa. Mahasiswa dalam memecahkan masalah mengalami kesulitan yang dipengaruhi oleh adversity quotient, yang merupakan kecerdasan mengatasi kesulitan yang mengubah hambatan menjadi peluang (Diana, 2018).

Konsep berfikir yang logis merupakan dasar penting dalam proses menggambar dan berkreasi. Jika mahasiswa tidak tahu apa yang akan digambar atau apa yang akan dikreasikan, maka terjadi proses menggambar fantastik yang terkadang tidak logis. Fenomena ini muncul dalam menggambar bentuk, dimana cukup banyak mahasiswa baru yang dipengaruhi oleh komik Manga Jepang. Sosok figur manusia dalam gaya Manga tampak aneh, tidak proporsional dan sangat tidak logis. Penelitian tentang dampak dan pengaruh Manga terhadap kemampuan menggambar di Indonesia, belum ditemukan rujukannya, namun Manga dan Anime diyakini memiliki pengaruh negatif jika dikonsumsi terlalu banyak (Wahidati, 2018)

Jika mahasiswa yang belajar menggambar bentuk, dilarang untuk membuat gambar bergaya Manga, hal ini disebabkan oleh adanya kemungkinan mahasiswa sulit memahami konsep yang benar dan logis (Gambar 1). Menggambar suatu objek visual dengan tampilan yang kurang logis, baik dengan cara deformatif maupun abstraktif akan menimbulkan kerancuan berfikir para mahasiswa. Proporsi, tata letak, rana, adalah beberapa hal yang objektif dan terukur kualitasnya dalam proses menggambar. Jika proporsi, tata letak dan rana saja salah, maka secara keseluruhan kualitas gambar menjadi rendah.

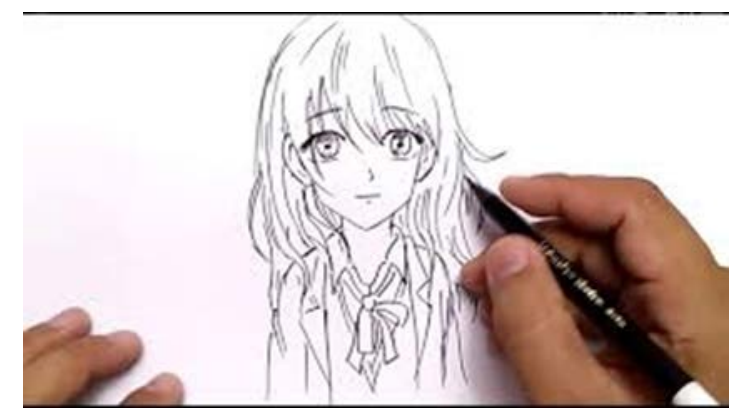

Gambar 1. Ekspresi Manga dan Anime (sumber: youtube.com) 
Edi Setiadi Putra \& Mohamad Arif Waskito

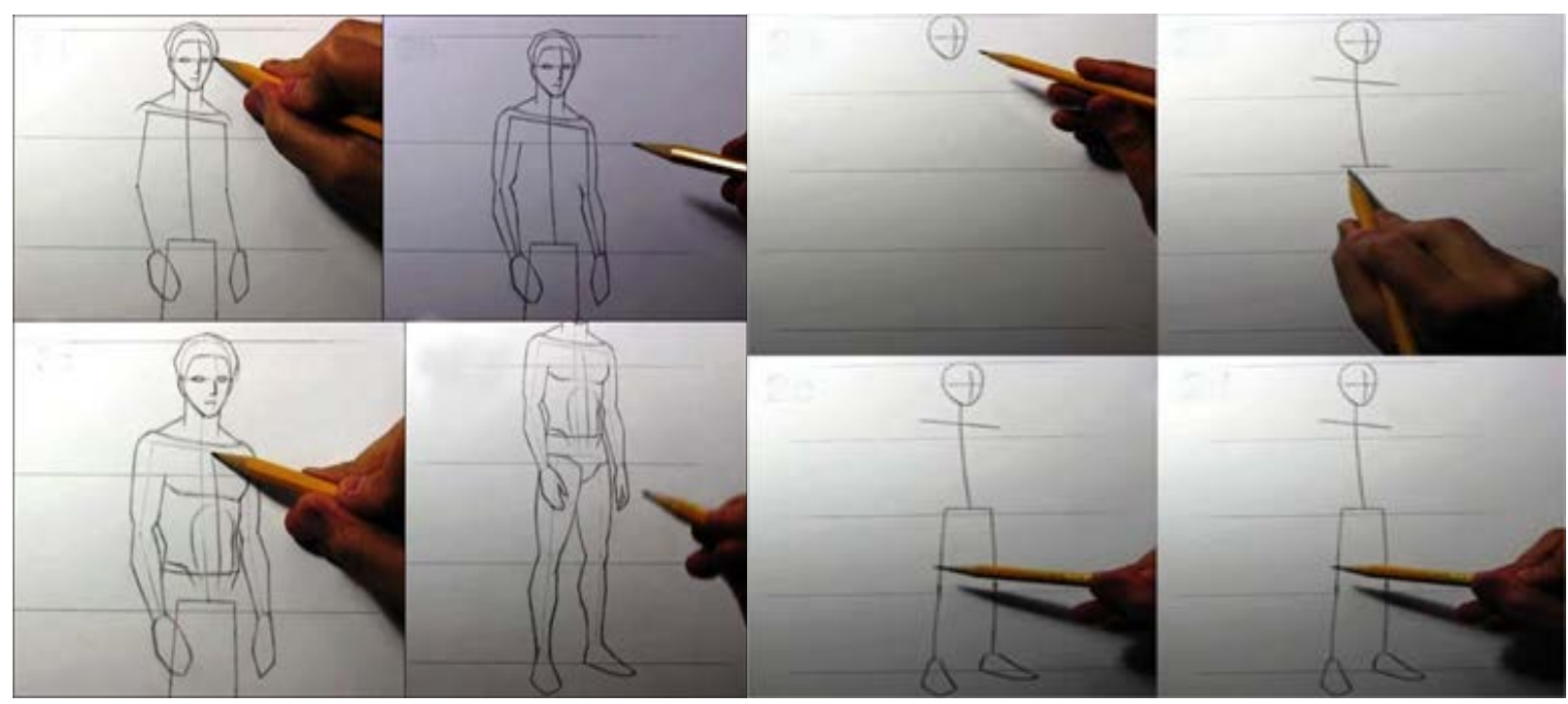

Gambar 2. Proses menggambar figur manusia (sumber: dictio.id)

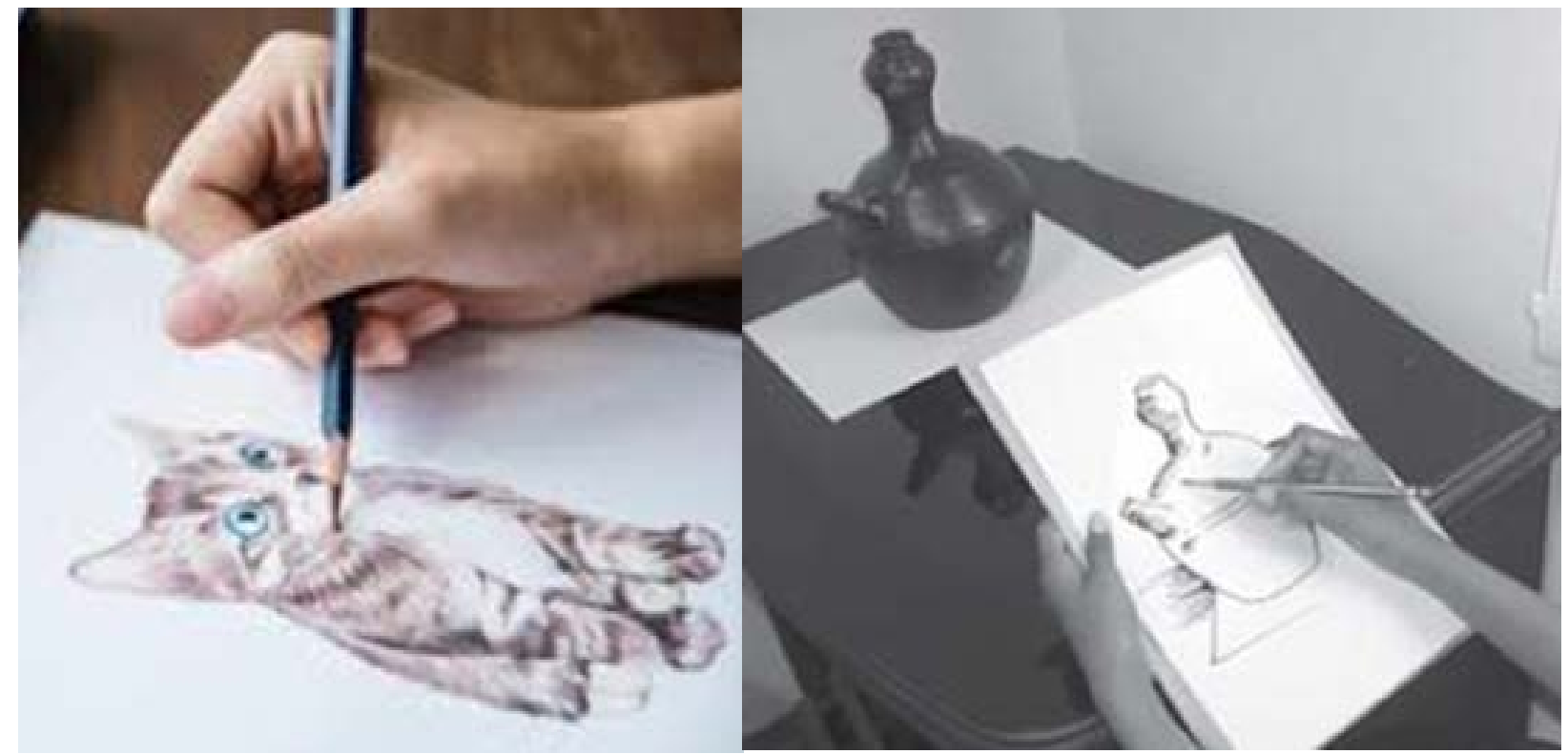

Gambar 3. Menggambar ekspresif naturalis (sumber: kumparan.com)

Latihan menggambar figur manusia, dapat dimaknai sebagai proses penerapan ilmu Ergonomi, yaitu mempertimbangkan variabilitas manusia yang memiliki perbedaan dalam visual karakter, visiognomi dan anatominya. Proporsi tubuh manusia pria dan wanita, berdasarkan perbedaan usia dan jenis kelamin, dapat dipahami mahasiswa sebagai tolok ukur yang mudah untuk menentukan pemahaman dan peningkatan kualitas logika. Melalui pemahaman sosok manusia sebagai prioritas utama dalam studi desain produk, maka mahasiswa dapat mempelajari ilmu ergonomi secara tidak langsung dalam pelajaran menggambar dan berkreasi. Dengan memahami kaidah ergonomi, mahasiswa dapat membuat gambar figur manusia yang baik dan benar (Gambar 2).

Bentuk figuratif dari suatu makhluk hidup dan benda-benda buatan manusia, merupakan tolok ukur yang paling mudah dipahami dalam mengetahui 
kualitas berfikir dan bertindak mahasiswa, sebab dapat dikomparasikan dengan bentuk sempurna dan benar yang ada di alam nyata. Jika seorang mahasiswa mampu menggambar sosok kucing seperti kucing hidup atau menggambar benda yang mirip dengan aslinya, maka dapat dipastikan ia telah menguasai aspek estetis yang terbangun dari proporsi yang benar, tekstur dan tata warna yang benar.

Latihan keterampilan menggambar pada dasarnya tidak hanya untuk menghasilkan karya gambar yang realistis, tetapi juga untuk memberikan pengalaman tentang rasa dan citra. Melalui arahan hati, kita dapat membedakan garis untuk menggambar bulu kucing dan garis untuk menampilkan tekstur kendi (Gambar 3).

Menggambar konstruktif merupakan cara memahami estetika melalui goresan garis yang membentuk bidang dan ruang geometris yang sangat logis. Perpotongan garis lurus, garis lengkung, garis sejajar, garis diagonal, berpadu satu membentuk satu citra visual yang memiliki makna. Konsep garis yang membentuk bidang dan bidang yang berpadu membentuk ruang, merupakan sistematika berfikir dua dimensi dan tiga dimensi yang sangat penting dalam mengkonstruksi ruang dan benda-benda terukur. Kemahiran ini tentu sangat diperlukan dalam memahami ruang, terutama dalam studi desain interior dan arsitektur.

Selain kemampuan teknis menggambar konstruktif dengan tangan bebas, mahasiswa perlu belajar memahami konsep ruang dengan terukur dan sistematis, minimal dalam memperkirakan dimensi dan cara kerja manusia di dalamnya. Jika menggambar kendaraan dengan media garis konstruktif, seorang perancang produk harus memikirkan psikologis manusia yang berada di dalamnya, terutama terkait dengan cara duduk, cara mengemudi dan berbagai kegiatan lain yang terdeteksi secara visual (Gambar 4). Perilaku manusia dan perubahannya sangat penting untuk dipelajari dalam proses visualisasi figur dan sikap manusia, sebagai perspektif perilaku sosial yang berpengaruh dalam dunia desain.Perspektif perilaku menyatakan bahwa perilaku sosial kita paling baik dijelaskan melalui perilaku yang secara langsung dapat diamati dan lingkungan yang menyebabkan perilaku kita berubah. Perspektif kognitif menjelaskan perilaku sosial kita dengan cara memusatkan pada bagaimana kita menyusun mental (pikiran, perasaan) dan memproses informasi yang datangnya dari lingkungan (Mustafa, 2011).

Penerapan sistem manusia dalam sketsa gambar, baik berupa ruang interior dan kendaraan, memerlukan pemahaman tentang perilaku manusia
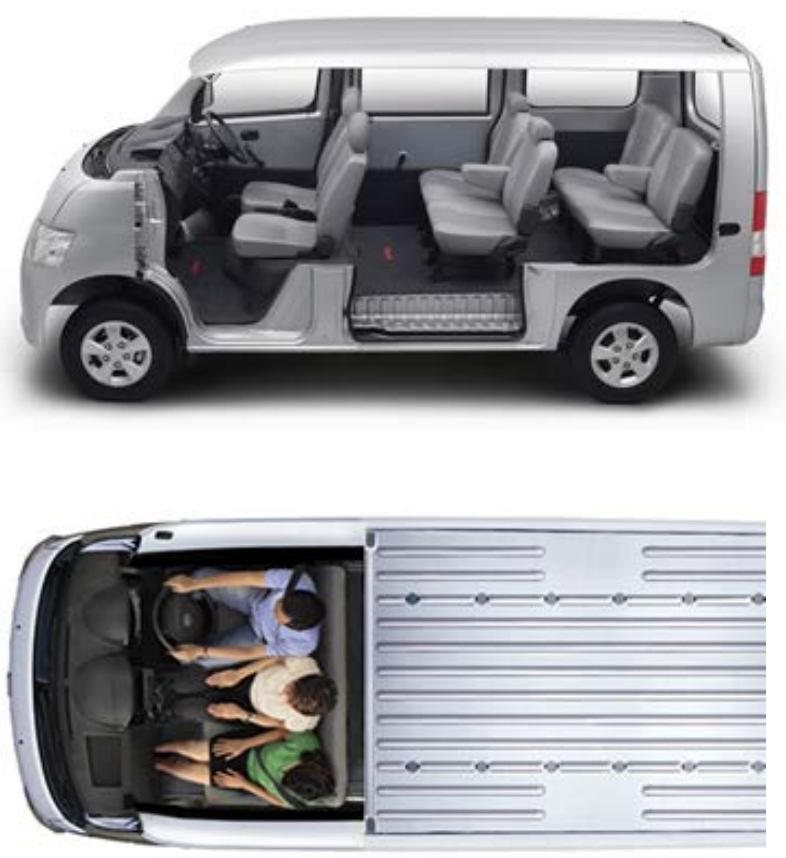

Gambar 4. Implementasi prinsip ergonomi dalam desain kendaraan (sumber: daihatsu.co.id)

dalam ruang interior rumah maupun ruang interior kendaraan. Dinamika perilaku manusia merupakan unsur ergonomi yang perlu mendapatkan perhatian, karena terkait dengan aspek budayanya. Pengaruh aspek budaya dalam ilmu ergonomi merupakan hal yang sangat penting untuk diperhatikan, terutama yang menyangkut pekerjaan khas yang dilakukan di beberapa bangsa dan wilayah tertentu di Indonesia.

Batasan budaya dalam ergonomi, terlihat dalam upaya melibatkan unsur kebiasaan lokal yang bisa saja berbeda paham dengan konsep global. Misalnya dalam perancangan sarana sanitasi untuk hotel bernuansa Sunda, desainer diharapkan menghindari penggunaan bathtube, dan lebih baik menggantinya dengan shower atau pancuran air, karena dalam adat istiadat Sunda, masyarakat meyakini lebih sehat mandi dengan pancuran air mengalir daripada mandi dengan genangan air. Dalam budaya Sunda, makhluk yang biasa mandi dalam genangan air, hanyalah kerbau, badak, dan gajah.

\section{Kesimpulan}

Penelitian ini menyoroti pentingnya proses berfikir dan bertindak logis sebagai salah satu kunci untuk 
memahami estetika. Berbagai metode pembelajaran menggambar dan berkreasi pada dasarnya bertujuan untuk memudahkan mahasiswa memahami makna dan fungsi estetika pada hasil kreasinya. Makna estetis yang terkandung dalam suatu produk kreasi,

Pola pemahaman estetika dalam matakuliahmatakuliah rupa dasar, seperti menggambar bentuk, menggambar konstruktif, kreasi rupa dasar dua dimensi dan kreasi rupa dasar tiga dimensi, masih berujung pada kesepakatan nilai indah (dalam hal ini pemahaman makna cantik, rapi, resik dan serasi) dengan sedikit mengabaikan nilai benar yang berlandaskan narasi logika.

Penerapan logika berfikir dalam pendidikan dasar desain (basic design training) merupakan elemen yang sangat penting dan berpengaruh kuat pada nilai benar dari suatu kreasi. Dasar logika yang dianut meliputi pemahaman wujud kreasi yang masuk akal (common sense) sehingga dapat diuraikan secara sederhana dan runut. Suatu kreasi yang muncul dari pemikiran sederhana yang masuk akal, merupakan pengaruh dari akar budaya pembuat kreasi. Sejak awal nilai-nilai estetika yang logis harus diterapkan dalam setiap matakuliah studio rupa dasar, karena merupakan dasar pondasi untuk terbiasa menciptakan kreasi yang dapat diargumentasikan sebagai karya ilmiah yang sarat dengan akademis.

Dalam praktek menggambar bentuk tingkat awal, mahasiswa perlu memahami objek gambar dengan benar, baik dimensi proporsi, tekstur dan warna yang objektif natural. Sehingga dapat memahami mengapa Tuhan YME menciptakan kreasi dengan wujud dan bentuk seperti itu. Dalam menggambar daun, tanaman perdu maupun pohon besar, mahasiswa perlu merasakan bagaimana tanaman itu tumbuh, berkolaborasi dengan air, tanah, angin dan panas sinar matahari. Pada setiap objek makhluk hidup, terdapat jejak tumbuh dan berkembang yang membedakan satu objek dengan objek lainnya. Jejak tumbuh dan perkembangan hidup suatu objek makhluk hidup, memiliki karakter tersendiri yang sulit dimanipulasi dengan kreasi fantasi.

Dalam menggambar sosok manusia, mahasiswa harus memperhatikan adanya perbedaan variatif dalam dimensi, proporsi, sikap, gerak dan reaksi reflektif terhadap situasi dan kondisi lingkungan. Menggambar sosok manusia akhirnya menjadi media untuk memahami prinsip ergonomi. Ilmu ergonomi merupakan salah satu pengetahuan yang penting untuk dipahami mahasiswa sejak awal, karena terkait dengan prinsip kelayakan pakai, dimana manusia pemakai alat sebagai prioritas utama.
Ilmu ergonomi yang dipelajari mahasiswa desain produk di Indonesia, mestilah terkait dengan prinsip kebudayaan Indonesia, karena cukup banyak kasus penerapan ergonomi yang tidak berlandaskan budaya sendiri. Keputusan desain dengan penerapan prinsip ergonomi yang tidak berlandaskan budaya bangsa, mengakibatkan desain produk yang dihasilkan menjadi agen budaya asing.

Nilai ergonomis yang dihasilkan dari penerapan prinsip ergonomi yang berlandaskan nilai budaya bangsa, merupakan ergonomi berbudaya (ergonomical cultural principles) yang menjamin terpeliharanya nilai-nilai budaya dalam suatu keputusan desain produk. Prinsip kultural ergonomi dapat ditemukan dari budaya suatu bangsa dalam menghadapi suatu pekerjaan prosedural, pola kebiasaan dan pemahaman nilai-nilai ergonomi universal itu sendiri, seperti prinsip produktivitas, kenyamanan kerja, efisiensi proses kerja dan efektivitas hasil kerja.

Penelitian implementasi prinsip ergonomi kultural dalam proses pemahaman nilai-nilai estetika, hanya mencakup proses pemahaman estetika dalam studio dasar desain di Itenas. Dengan demikian, penelitian ini masih harus dikembangkan lagi di institusi pendidikan desain produk yang lain, dengan lebih fokus kepada beberapa matakuliah studio dasar desain yang lainnya. Penelitian ini merupakan perintis yang mengupas keberadaan nilai-nilai ergonomi kultural dalam studi dasar desain, yang masih sangat membutuhkan rujukan dan proses kajian yang lebih mendalam.

Semoga penelitian ini memberikan manfaat bagi berbagai pihak, terutama bagi kalangan pengajar estetika dalam studio dasar desain untuk terus memberikan pemahaman nilai-nilai estetika yang dapat dimengerti mahasiswa secara lugas dari berbagai sudut pandang keilmuan.

Terimakasih dihaturkan kepada penyelenggara Seminar Nasional Redefinisi Pendidikan Dasar Desain ITSB Tahun 2019, Afiliasi Program Studi Desain Produk Industri Indonesia, serta Jurnal Productum Jurnal Desain Produk ISI Yogyakarta. Semoga kerjasama antar institusi Prodi Desain Produk Indonesia dan ADPII, kian terjalin dan semakin menghasilkan prestasi yang berkualitas tinggi.

\section{Daftar pustaka}

Diana, N. (2018). Mengembangkan Kemampuan Berpikir Kreatif dan Berpikir Logis Mahasiswa dengan Adversity Quotient dalam Pemecahan Masalah. Prosiding SNMPM II Prodi Pendidikan Matematika. Cirebon: SNMPM II. 
Mudji Sutrisno, d. (2017). Teks-teks Kunci Estetika: Filsafat Seni. 1st Ed. Yogyakarta: Galangpress.

Mustafa, H. (2011). Perilaku Manusia Dalam Perspektif Psikologi Sosial. Jurnal Administrasi Bisnis, Vol.7 No.2, 143-156.

Wahidati, L. (2018). Pengaruh Konsumsi Anime dan Manga
Terhadap Pembelajaran Budaya dan Bahasa Jepang. Izumi Vol 7 No.1 E-Jurnal Universitas Diponegoro, 1-10.

Wallschlaeger, C., \& Busic-Snyder, C. (1992). Basic Visual Concepts and Principles. IA USA: Win.C Brown Publisher. 